\title{
Factors Influencing CSR Initiatives of the Banks in Oman: A Study Based on Stakeholders' Perspective
}

\author{
K.Sangeetha (Corresponding author) \\ Shinas College of Technology \\ PO Box 77; Post code 324, Al Aqr, Sultanate of Oman \\ Tel: 968-2685-2800Ｅ-mail: sangeetha.comm@gmail.com
}

\begin{abstract}
S. Pria
Shinas College of Technology

PO Box 77; Post code 324, Al Aqr, Sultanate of Oman

Tel: 968-2685-2800Ｅ-mail: dr.s.pria@gmail.com
\end{abstract}

Received: March 11, 2011 Accepted: March 26, 2011 doi:10.5296/jmr.v3i2.609

\begin{abstract}
Corporate social responsibility is one among the top prioritized agenda of any business organization. Many business organizations embraced CSR in a befitting manner and are evident from the number of activities undertaken by them. This paper aims to study the factors influencing the CSR initiatives of the banks in Sultanate of Oman. This is based on the major stakeholders' perspective towards philanthropic angle of the banks. This study has its rational as the banks represent majority of the financial institutions in Oman. From this study, factors that influence the CSR activities of the banks are identified along with predominant factors that influence banks towards their social pursuits. The application of this research is to understand the stakeholders' views and is expected to throw some more light into the societal perspective of the banks. This paper contributes to the existing literature in CSR activities of the banks and stakeholders participation in CSR.
\end{abstract}

Keywords: Corporate Social Responsibility (CSR), Factors, Principal Component Analysis, Stakeholders, Sultanate of Oman. 


\section{Introduction}

Corporate social responsibility is a form of corporate self-regulation integrated into a business model. CSR policy functions as a built-in, self-regulating mechanism whereby business monitors and ensures its active compliance with the spirit of the law, ethical standards and international practices. The goal of CSR is to embrace responsibility of the company's actions and encourage a positive impact through its activities on the environment, consumers, employees, communities, stakeholders and all other members of the public sphere (Wikipedia). There are numerous benefits of CSR to the business units and this includes (i) CSR efforts are part of the global citizenship initiative of the business; (ii) combat negative publicity; (iii) helps to recruit, motivate, and retain employees; (iv) attract consumers to buy a company's products or subscribe to their services; (v) reduction in costs through waste reduction; eco friendly operations and energy conservation; (vi) integral part of a company's risk management efforts; (vii) marketing strategy to disseminate the company profile to the minds of the stakeholders (Sprinkle \& Maines, 2010). CSR can serve as a highly effective component of internal marketing programs by fulfilling employee needs and drawing them to identify strongly with the company. Thus, CSR activity is capable of yielding substantial returns to both employee and company. Companies those are able to realign their diversity initiative along with CSR and multicultural marketing are able to achieve new levels in adding value to their system. Integrating diversity, CSR, and multicultural marketing adds value in four ways: It creates a stronger company, a better place to work, deploys resources more efficiently and reduces waste. Global companies and companies that focus on multicultural consumers are in the best position to benefit from their approach of aligning cultural diversity, CSR and multinational employees(Palacios, 2008). The role of financial sector in contributing to sustainable development is considerable because of its intermediary role in an economic system. Also the financial sector could play a crucial role in influencing companies to address CSR issues (Sparkes \& Cowton, 2004). Hence it is rationale to study the banks as it the major player in the financial sector especially in Sultanate of Oman.

\section{Stakeholders Participation in CSR and its Strategic Implications}

Firms are benefited by their CSR strategies by getting consumers' positive product and brand evaluations, brand choice and recommendations (Sen \& Bhattacharya, 2001). CSR initiatives allow consumers to identify with the company on the basis of perceived overlap between their own identities and that of the company (Lichtenstein et al., 2004). CSR is identified as one of the factors that influence consumer behavior at a time the customers are demanding more from the firms. Consumers can choose to evaluate a company based on whether the organization acts in a manner consistent with supporting the welfare of the community and society (Maignan et al., 2005). Consumers are greatly influenced by their company's level of CSR activities for the reputation and their purchase intentions (Mohr \& Webb, 2005). There exists a direct link between CSR and customer satisfaction (Luo \& Bhattacharya, 2006). CSR is also considered for its role as an internal marketing strategy due to the fact that companies find it difficult to attract, retain and motivate talented employees (Bhattacharya et al., 2007). Stakeholder's expectations are important for achieving company's financial performance as well as recognition from the society. Formation of close relationships with the various kinds 
of stakeholders is an indispensable part of the business and also it is not possible for the companies to create value without the active participation of the stakeholders. CSR activities have a significant influence on several consumer related outcomes such as consumer product responses (Pirsch et al., 2007), attitudes (Berens et al., 2005) and consumer company identification (Bhattacharya \& Sen, 2004). It is mentioned that one of the ways to build better corporate reputation of the banks through the efficient sustainable management of stakeholders. This will help the banks to preserve market positions, margins and organizational vitality. A corporate reputation is a broad entity that enables a bank to establish a relationship with their stakeholders and encompasses the full range of attributes associated with the underlying products and service experience. Based on the assumption that consumers will reward firms for their support of social programs, many organizations have adopted corporate social responsibility (CSR) practices. CSR initiatives are linked to stronger loyalty due to positive company evaluation by the consumers. Moreover, identity salience is shown to play a crucial role in the influence of CSR initiatives on consumer loyalty when this influence occurs through consumer-company identification. As long as the CSR initiatives undertaken by the company are perceived as central, distinctive, and enduring, they will contribute to the prestige of the company. Effects of CSR activities are also influenced by the salience of the firm. CSR associations to consumer loyalty led to better managers' understanding of the possibilities of the company CSR investments (Marin et al., 2009). Hence there is august need to study bank’s CSR from stakeholder's perspective.

\section{Research Methodology}

\subsection{Research Aim}

This study aims to investigate the influential factors of bank's CSR initiatives. Banking sector contributes to $90 \%$ of the financial institutions in Oman. The banking sector in Oman is mainly dominated by the national banks. There are seven national banks in Oman: Ahli Bank, Bank Dhofar, Bank Muscat, Bank Sohar, National Bank of Oman, Oman Arab Bank and Oman International Bank. These seven banks are selected as they represent more than $90 \%$ of the credit share of the banks in Sultanate of Oman (Business Today, June, 2010). Hence in this research, stakeholders from these seven banks are only considered to register their opinion on the proposed research theme.

\subsection{Survey Instrument}

From the literature survey, the major stakeholders groups of the banking sector are identified and their perspective is recorded through the structured questionnaire. This questionnaire consisting of mainly close-ended type of questions with a few open-ended type of questions was constructed for the study. This questionnaire was designed to seek general information of the respondents, factors that influence the CSR activities along with other metrics related to the research area. Respondents were asked to rate on a 5-point Likert scale a list of statements such as (a) Bank is less likely to invest in CSR if their financial performance is weak; (b) Bank's CSR depends on the strategies of the competitors; (c) CSR contributions are more if the bank is having well organized and self regulated corporate governance system; (d) CSR activities are positively related to diversity and nature of workforce; (e) CSR activities 
depend on the existence of stronger NGOs, private and independent social organizations; (f) Bank that employ performance based reward/effective staff appraisal system is more inclined towards CSR; (g) Multinationals in top management greatly influence the CSR policy; (h) Bank spends for CSR to evade taxes; (i) Central Bank/ regulator interference increases the CSR spending and (j) CSR policies are just only the mimics of western culture and bank in Oman try to emulate multinationals in this aspect. The questionnaire was originally prepared in English and then translated into Arabic by using the backward translation method with an assistant from a third party who was fluent in both languages to avoid translation bias and error. Only minor discrepancies were observed between the original instrument and its back translated version and hence it was easily resolved by the translator.

Before the final version of the questionnaire was sent out, it was pilot tested to determine the appropriateness and relevance of the questions in the instrument. This early draft was circulated and piloted among the sample stakeholders that include business people, customers, local community and bank employees to receive their feedback. Based on the feedback from these respondents, several modifications were made to the wording of few questions. The final version of the questionnaire was then distributed to six stakeholder groups of national banks in Oman. The stakeholder groups are customers, investors, local community, branch managers, employees, management thinkers and academicians. The choice of these diverse groups was based on the grounds that they represent the primary groups of stakeholders of banks in Oman. It follows closely the widely quoted definition of stakeholders, defined as "any group or individual who can affect or is affected by the achievement of the firm's objectives" (Freeman 1984). Table 1 shows the demographic and other related information of the stakeholders who participated in this research. Response rate for the questionnaire is found to be $78.09 \%$. This is good response rate to validate the sample used for the research.

\subsection{Hypothesis Development}

The following are the hypotheses framed to study the factors that influence CSR initiatives of the banks:

H1: There is no significant difference among the stakeholders on the degree of disagreement that bank spending in CSR depends on their financial performance and CSR policies depend on the strategies of the competitors.

H2: Stakeholders of banks in Oman are having no significant difference on the degree of agreement that CSR is related to well organized corporate governance, diversity of workforce and related to system that offers their employees’ performance based rewards.

H3: Stakeholders of Banks in Oman are showing no significant differences in agreeing to the statement that CSR activities depend on the existence of the social organizations and multinationals in the top management.

H4: There is no significant difference among the stakeholders on the degree of disagreement that banks spend for CSR to evade taxes and due to central bank and regulators interference. 
H5: There is no significant difference among the stakeholders on the degree of disagreement that CSR policies of the banks in Oman are just only the mimics of western culture and lacks indigenous element.

Table 1. Profile of the Stakeholders

\begin{tabular}{|l|l|}
\hline Gender & Male/Female \\
\hline Age Group (Years) & Below 20; 21-30; 31-40; 41-50; Above 50 \\
\hline Marital Status & Single/Married \\
\hline $\begin{array}{l}\text { Highest Educational } \\
\text { Qualification }\end{array}$ & $\begin{array}{l}\text { Primary school; Secondary school; Diploma; Bachelors; } \\
\text { Masters; Ph.D }\end{array}$ \\
\hline Professional Affiliation & $\begin{array}{l}\text { Unemployed/Student; Working in government/ministry; } \\
\text { Private sector; Business }\end{array}$ \\
\hline Monthly Income in RO & $\begin{array}{l}\text { Below 100 ; 100-200; 201-500; 501-800; 801-1000; Above } \\
1000\end{array}$ \\
\hline Native Region/Wilayat & $\begin{array}{l}\text { Al Batinah (North/ South); Dhofar; Dhakiliya; Dhahirah; Al } \\
\text { Wusta; Muscat (South / Central /North); Sharqiya }\end{array}$ \\
\hline Stakeholder Relationship & $\begin{array}{l}\text { Customer; Investor; Local Community; Employee; Manager; } \\
\text { Management thinker/Academician }\end{array}$ \\
\hline Bank & $\begin{array}{l}\text { Ahli Bank; Bank Dhofar; Bank Muscat; Bank Sohar; National } \\
\text { Bank of Oman; Oman Arab Bank; Oman International Bank }\end{array}$ \\
\hline Years of Association & Less than one year; 2-5; 6-10; 11-20; Above 20 years \\
\hline Nationality & Omani/Expatriate \\
\hline
\end{tabular}

\section{Findings and Analysis}

Statistical analysis of the survey instrument is carried out by SPSS17. Descriptive analysis of the stakeholders' views is given in Table 2 for all the hypotheses. Table 3 gives the results of nonparametric test i.e. Kruskal Wallis test. From Table 2, it is inferred that stakeholders seem to hold a consistent view in disagreeing to the statement that bank is less likely to invest in CSR if their financial performance is weak. Majority of the respondents (82.9\%) disagreed while $13.7 \%$ neutral and only $3.4 \%$ agreed to the statement. Chi square value for statement 1 is 7.858 below the critical value of 10.967 for five degrees of freedom. Sig. value is 0.164. In case of statement 2, CSR depends on the strategies of the competitors, majority of the stakeholders (78.9\%) disagreed while $12.1 \%$ maintained neutral and only $9 \%$ agreed to the statement. Chi square value for statement 2 is 5.603 and sig. value of 0.347 . Hence H1 is accepted as there is no significant difference on the degree of disagreement. Table 4 contains the summary of the hypotheses used in this research. 
Table 2. Descriptive Statistics of Factors Influencing CSR

\begin{tabular}{|l|c|c|c|c|c|c|c|c|c|c|c|}
\hline \multicolumn{2}{l|}{} & \multicolumn{9}{|c|}{ Percentage of Stakeholders } \\
\hline Statement & 1 & 2 & 3 & 4 & 5 & 6 & 7 & 8 & 9 & 10 \\
\hline Rating scale & Value & & & & & & & & & & \\
\hline $\begin{array}{l}\text { Strongly } \\
\text { Disagree }\end{array}$ & 1 & 41.2 & 40.2 & 0.9 & 6.4 & 0.4 & 0.9 & 2.8 & 17.8 & 43.2 & 44.4 \\
\hline Disagree & 2 & 41.7 & 38.7 & 2.7 & 7.3 & 1.6 & 9.4 & 6.0 & 33.2 & 40.1 & 40.5 \\
\hline Subtotal \% & & 82.9 & 78.9 & 3.6 & 13.7 & 2.0 & 10.3 & 8.8 & 51 & 83.3 & 84.9 \\
\hline Neutral & 3 & 13.7 & 12.1 & 19.1 & 17.7 & 14.6 & 16.7 & 19.7 & 27.3 & 9.9 & 11.5 \\
\hline Agree & 4 & 3.2 & 5.2 & 45.3 & 39.1 & 37.8 & 32.3 & 35.3 & 16.9 & 6.4 & 3.4 \\
\hline $\begin{array}{l}\text { Strongly } \\
\text { Agree }\end{array}$ & 5 & .2 & 3.8 & 32.0 & 29.5 & 45.6 & 40.7 & 36.2 & 4.8 & 0.4 & 0.2 \\
\hline Subtotal \% & & 3.4 & 9.0 & 77.3 & 68.6 & 83.4 & 73 & 71.5 & 21.7 & 6.8 & 3.6 \\
\hline Mean Value & & 1.79 & 1.76 & 4.05 & 3.78 & 4.27 & 4.03 & 3.96 & 2.58 & 1.81 & 1.74 \\
\hline $\begin{array}{l}\text { Median } \\
\text { Value }\end{array}$ & & 2 & 2 & 4 & 4 & 4 & 4 & 4 & 2 & 2 & 2 \\
\hline Mode Value & & 2 & 1 & 4 & 4 & 5 & 5 & 5 & 2 & 1 & 1 \\
\hline $\begin{array}{l}\text { Standard } \\
\text { Deviation }\end{array}$ & & 0.807 & 0.797 & 0.835 & 1.137 & 0.792 & 1.002 & 1.027 & 1.108 & 0.885 & 0.804 \\
\hline
\end{tabular}

77.3\% of the stakeholders agree that CSR contributions are more if the corporate is having well organized and self regulated corporate governance system. 3.6\% disagree and $19.1 \%$ are indifferent to this opinion with mean value of 4.05 and standard deviation of 0.835 . Chi square value is 32.063 with sig. value of 0.000 indicates that there is significant difference among the stakeholders. Majority of the stakeholders (68.6\%) judged CSR activities are positively related to the diversity and nature of the workforce. $13.7 \%$ disagreed the role of diversity and $17.8 \%$ are neutral with mean value of 3.78 and standard deviation 0.835 . Chi square value is 58.488 for statement 4 with sig. value 0.000 . This indicates that there is significant difference among the stakeholders. For the statement 6, bank that employ performance based reward/effective staff appraisal system is more inclined towards CSR, $73 \%$ agreed whereas $10.3 \%$ of the stakeholders disagreed with $16.7 \%$ neutral with mean value is 4.03 and standard deviation of 1.002 . Chi square value is 40.989 and sig. value is 0.000 . Hence $\mathrm{H} 2$ is rejected due to significant difference in the degree of agreement among the respondents.

For statement 5, CSR activities depend on the existence of stronger NGOs, private and independent social organizations, $83.4 \%$ of the stakeholders agreed with $2 \%$ disagreed and $14.6 \%$ maintained neutral. Chi square value for statement 5 is 5.654 with five degrees of freedom and sig. value is 0.341. Similarly for the statement 7, multinationals in top management greatly influence the CSR policy, 8.8\% disagree, $19.7 \%$ neutral and $71.5 \%$ agreed to the statement. Chi square is 7.378 and sig. value is 0.194 with mean value of 3.96 and standard deviation of 1.027. Hence H3 is accepted as there is not much of deviation in 
the degree of agreement among the respondents.

Table 3. Kruskal Wallis Test

\begin{tabular}{|c|c|c|c|c|c|c|}
\hline Statement 1 & Relationship with Bank & $\mathbf{N}$ & Mean Rating & Chi & df & Sig. \\
\hline \multirow{6}{*}{$\begin{array}{l}\text { Bank is less likely to invest in } \\
\text { CSR if their financial } \\
\text { performance is weak }\end{array}$} & Customer & 123 & 300.36 & \multirow[t]{7}{*}{7.858} & \multirow[t]{7}{*}{5} & \multirow[t]{7}{*}{0.164} \\
\hline & Investor & 103 & 305.50 & & & \\
\hline & Local Community & 124 & 272.11 & & & \\
\hline & Employee & 103 & 266.33 & & & \\
\hline & Manager & 43 & 252.69 & & & \\
\hline & Management Thinker/Academician & 67 & 273.37 & & & \\
\hline \multicolumn{4}{|l|}{ Statement 2} & & & \\
\hline \multirow{6}{*}{$\begin{array}{l}\text { CSR depends on the strategies } \\
\text { of the competitors }\end{array}$} & Customer & 123 & 305.50 & \multirow[t]{6}{*}{5.603} & \multirow[t]{6}{*}{5} & \multirow[t]{6}{*}{0.347} \\
\hline & Investor & 103 & 289.26 & & & \\
\hline & Local Community & 124 & 268.43 & & & \\
\hline & Employee & 103 & 273.33 & & & \\
\hline & Manager & 43 & 259.58 & & & \\
\hline & Management Thinker/Academician & 67 & 280.53 & & & \\
\hline \multicolumn{7}{|l|}{ Statement 3} \\
\hline \multirow{6}{*}{$\begin{array}{l}\text { CSR contributions are more if } \\
\text { the corporate is having well } \\
\text { organized and self regulated } \\
\text { corporate governance system }\end{array}$} & Customer & 123 & 262.41 & \multirow[t]{6}{*}{32.063} & \multirow[t]{6}{*}{5} & \multirow[t]{6}{*}{0.000} \\
\hline & Investor & 103 & 266.25 & & & \\
\hline & Local Community & 124 & 238.50 & & & \\
\hline & Employee & 103 & 333.73 & & & \\
\hline & Manager & 43 & 317.50 & & & \\
\hline & Management Thinker/Academician & 67 & 320.37 & & & \\
\hline \multicolumn{7}{|l|}{ Statement 4} \\
\hline \multirow{6}{*}{$\begin{array}{l}\text { CSR activities are positively } \\
\text { related to diversity and nature } \\
\text { of workforce (employees from } \\
\text { different nationalities studied } \\
\text { in various business schools) }\end{array}$} & Customer & 123 & 236.74 & \multirow[t]{6}{*}{58.488} & \multirow[t]{6}{*}{5} & \multirow[t]{6}{*}{0.000} \\
\hline & Investor & 103 & 229.11 & & & \\
\hline & Local Community & 124 & 309.77 & & & \\
\hline & Employee & 103 & 269.97 & & & \\
\hline & Manager & 43 & 335.57 & & & \\
\hline & Management Thinker/Academician & 67 & 379.12 & & & \\
\hline \multicolumn{7}{|l|}{ Statement 5} \\
\hline \multirow{6}{*}{$\begin{array}{l}\text { CSR activities depend on the } \\
\text { existence of stronger NGOs, } \\
\text { private and independent social } \\
\text { organizations in the society }\end{array}$} & Customer & 123 & 286.53 & \multirow[t]{6}{*}{5.654} & \multirow[t]{6}{*}{5} & \multirow[t]{6}{*}{0.341} \\
\hline & Investor & 103 & 256.28 & & & \\
\hline & Local Community & 124 & 274.17 & & & \\
\hline & Employee & 103 & 300.71 & & & \\
\hline & Manager & 43 & 295.58 & & & \\
\hline & Management Thinker/Academician & 67 & 290.22 & & & \\
\hline Statement 6 & Relationship with Bank & $\mathbf{N}$ & Mean Rating & Chi & df & Sig. \\
\hline \multirow{5}{*}{$\begin{array}{l}\text { Bank that employ performance } \\
\text { based reward/effective staff } \\
\text { appraisal system is more } \\
\text { inclined towards CSR }\end{array}$} & Customer & 123 & 213.35 & 40.989 & 5 & 0.000 \\
\hline & Investor & 103 & 282.89 & & & \\
\hline & Local Community & 124 & 304.35 & & & \\
\hline & Employee & 103 & 329.96 & & & \\
\hline & Manager & 43 & 322.74 & & & \\
\hline
\end{tabular}




\begin{tabular}{|c|c|c|c|c|c|c|}
\hline & Management Thinker/Academician & 67 & 265.43 & & & \\
\hline \multicolumn{7}{|l|}{ Statement 7} \\
\hline \multirow{6}{*}{$\begin{array}{l}\text { Multinationals in top } \\
\text { management greatly influence } \\
\text { the CSR policy }\end{array}$} & Customer & 123 & 287.47 & \multirow[t]{6}{*}{7.378} & \multirow[t]{6}{*}{5} & \multirow[t]{6}{*}{0.194} \\
\hline & Investor & 103 & 300.27 & & & \\
\hline & Local Community & 124 & 250.66 & & & \\
\hline & Employee & 103 & 282.53 & & & \\
\hline & Manager & 43 & 289.67 & & & \\
\hline & Management Thinker/Academician & 67 & 296.14 & & & \\
\hline \multicolumn{7}{|l|}{ Statement 8} \\
\hline \multirow{6}{*}{$\begin{array}{l}\text { Bank spends for CSR to evade } \\
\text { taxes }\end{array}$} & Customer & 123 & 369.83 & \multirow[t]{7}{*}{185.432} & \multirow[t]{7}{*}{5} & \multirow[t]{7}{*}{0.000} \\
\hline & Investor & 103 & 298.77 & & & \\
\hline & Local Community & 124 & 369.97 & & & \\
\hline & Employee & 103 & 173.98 & & & \\
\hline & Manager & 43 & 141.60 & & & \\
\hline & Management Thinker/Academician & 67 & 188.32 & & & \\
\hline \multicolumn{4}{|l|}{ Statement 9} & & & \\
\hline \multirow{6}{*}{$\begin{array}{l}\text { Central Bank/ regulators } \\
\text { interference increase } \\
\text { spending }\end{array}$} & Customer & 123 & 360.56 & \multirow[t]{6}{*}{47.186} & \multirow[t]{6}{*}{5} & \multirow[t]{6}{*}{0.000} \\
\hline & Investor & 103 & 251.31 & & & \\
\hline & Local Community & 124 & 265.33 & & & \\
\hline & Employee & 103 & 262.25 & & & \\
\hline & Manager & 43 & 294.41 & & & \\
\hline & Management Thinker/Academician & 67 & 238.21 & & & \\
\hline \multicolumn{7}{|l|}{ Statement 10} \\
\hline \multirow{6}{*}{$\begin{array}{l}\text { CSR policies are just only the } \\
\text { mimics of western culture } \\
\text { and bank in Oman try to } \\
\text { emulate multinationals in this } \\
\text { aspect }\end{array}$} & Customer & 123 & 282.35 & \multirow[t]{6}{*}{8.578} & \multirow[t]{6}{*}{5} & \multirow[t]{6}{*}{0.127} \\
\hline & Investor & 103 & 267.79 & & & \\
\hline & Local Community & 124 & 273.38 & & & \\
\hline & Employee & 103 & 307.50 & & & \\
\hline & Manager & 43 & 317.35 & & & \\
\hline & Management Thinker/Academician & 67 & 257.28 & & & \\
\hline
\end{tabular}


Table 4. Hypothesis and Stakeholders Opinion

\begin{tabular}{|c|c|c|c|c|}
\hline Number & Hypothesis & $\begin{array}{l}\text { Nature of } \\
\text { Response }\end{array}$ & $\begin{array}{l}\text { Significant } \\
\text { Difference }\end{array}$ & Results \\
\hline H1 & $\begin{array}{l}\text { There is no significant difference among the } \\
\text { stakeholders on the degree of disagreement that } \\
\text { bank spending in CSR depends on their } \\
\text { financial performance and CSR policies depend } \\
\text { on the strategies of the competitors. }\end{array}$ & Disagreement & No & Accepted \\
\hline $\mathrm{H} 2$ & $\begin{array}{l}\text { Stakeholders of banks in Oman are having no } \\
\text { significant difference on the degree of } \\
\text { agreement that CSR is related to well organized } \\
\text { corporate governance, diversity of workforce } \\
\text { and related to system that offers their } \\
\text { employees' performance based rewards. }\end{array}$ & Agreement & Yes & Rejected \\
\hline H3 & $\begin{array}{l}\text { Stakeholders of Banks in Oman are showing no } \\
\text { significant differences in agreeing to the } \\
\text { statement that CSR activities depend on the } \\
\text { existence of the social organizations and } \\
\text { multinationals in the top management. }\end{array}$ & Agreement & No & Accepted \\
\hline $\mathrm{H} 4$ & $\begin{array}{l}\text { There is no significant difference among the } \\
\text { stakeholders on the degree of disagreement that } \\
\text { banks spend for CSR to evade taxes and due to } \\
\text { central bank and regulators interference. }\end{array}$ & Disagreement & Yes & Rejected \\
\hline H5 & $\begin{array}{l}\text { There is no significant difference among the } \\
\text { stakeholders on the degree of disagreement that } \\
\text { CSR policies of the banks in Oman are just } \\
\text { only the mimics of western culture and lacks } \\
\text { indigenous element. }\end{array}$ & Disagreement & No & Accepted \\
\hline
\end{tabular}

There is a negative view that banks are involved in CSR to evade taxes, statement 8 . Customers and local community endorses this view whereas investors, employees, mangers and management thinkers do not agree with this view. There is significant difference among the stakeholders in this issue which is evident from chi square value of 185.432 and sig. value is 0.000 . Mean value is 2.58 with standard deviation $1.108 .51 \%$ of the stakeholders disagree whereas $21.7 \%$ agree to this statement and $27.3 \%$ remained neutral. About $83.3 \%$ of the stakeholders disagree with the view that Central Bank/ regulator interference increases the CSR spending (statement 9). This view is common among all the stakeholders except customers. There is significant difference among the opinion expressed with chi square value of 47.186 and sig. value is 0.000 . There is significant difference to some degree among the ratings given by the stakeholders in disagreeing to the statement that central bank or the regulators interference increase the CSR spending by the banks. Table 2 indicate that $83.3 \%$ disagree while $6.8 \%$ agree to this view and others are neutral. Chi square value is 47.186 
which is well above the tabulated value of 10.967 for five degrees of freedom. Sig. value is 0.000. Mean value is 1.81 with median 2, indicates that stakeholders underplay the role of central bank or regulators role in determining the social expenditure budget of the banks. Hence $\mathrm{H} 4$ is rejected due to difference in the degree of disagreement among the various stakeholder groups.

Hypothesis 5 is accepted as there is no significant deviation among the stakeholders on the degree of disagreement that bank's CSR policies are just only the mimics of western culture and bank in Oman try to emulate multinationals in this aspect(statement 10). $84.9 \%$ of the stakeholders disagreed to emphasize the indigenous nature of the CSR policies whereas $11.5 \%$ remain neutral while $3.6 \%$ agree with a mean value of 1.74 and standard deviation of 0.804 .

Factor analysis is conducted to determine the variables that are correlated with each other, but relatively independent of other sets of data. Therefore it is possible to identify the dominant factors that found to influence the CSR activities from stakeholders perspective. Factors analysis is conducted for ten identified parameters such as financial performance, strategies of the competitors, corporate governance system, diversity of the workforce, existence of NGOs and social organizations, multinationals in top management, performance based appraisal practice, tax evasion, regulator interference and indigenous policy towards CSR.

Kaiser-Meyer Olkin test is conducted to measure the sampling adequacy. Bartett's test of sphercity is conducted to verify the correlation between variables. Table 5 shows the results obtained for both these tests. Value obtained for KMO test is 0.782 which indicates good measure of sampling adequacy. Bartlett's measure tests indicates that there are some relationship between variables and test is statistical significant (value less than 0.05). Both these tests justify the application of principal component analysis to the test data. These factors are also rotated using varimax rotation method with Kaiser Normalization. The outcomes of the variance by the extracted and rotated components are shown in Table 6 . Table 7 shows the component matrix and three major components extracted from ten factors identified to influence bank's CSR. From Table 7, the first component extracted with high correlation is existence of stronger NGOs, private and independent social organizations in the society. The second principal component extracted is corporate is having well organized and self regulated corporate governance system. Third component is diversity and nature of workforce. Table 8 shows the rotated component matrix and this result confirms three principal components extracted. So the predominant factors that influence the bank's CSR are presence of nongovernmental organizations and social organizations, good corporate governance system and diversity of the workforce. 
Table 5. KMO and Bartlett's Test - - Factors Influencing CSR

\begin{tabular}{|c|c|c|}
\hline \multicolumn{2}{|c|}{ Kaiser-Meyer-Olkin Measure of Sampling Adequacy } & .782 \\
\hline \multirow[t]{3}{*}{ Bartlett's Test of Sphericity } & Approx. Chi-Square & 844.907 \\
\hline & df & 45 \\
\hline & Sig. & .000 \\
\hline
\end{tabular}

Table 6. Total Variance of the Principal Components - Factors Influencing CSR

\begin{tabular}{|c|c|c|c|c|c|c|}
\hline \multirow{2}{*}{ Component } & \multicolumn{3}{|c|}{ Extraction Sums of Squared Loadings } & \multicolumn{3}{|c|}{ Rotation Sums of Squared Loadings } \\
\cline { 2 - 7 } & Total & \% of Variance & Cumulative \% & Total & \% of Variance & Cumulative \% \\
\hline 1 & 2.070 & 20.701 & 20.701 & 2.000 & 20.000 & 20.000 \\
\hline 2 & 1.819 & 18.186 & 38.887 & 1.832 & 18.317 & 38.317 \\
3 & 1.352 & 13.520 & 52.407 & 1.409 & 14.090 & 52.407 \\
\hline
\end{tabular}

Table 7. Principal Component Analysis of Factors Influencing CSR

\begin{tabular}{|l|c|c|c|}
\hline \multicolumn{1}{|c|}{ Component Matrix $^{\mathbf{a}}$} & \multicolumn{3}{|c|}{ Component } \\
\hline & 1 & 2 & 3 \\
\hline Bank is less likely to invest in CSR if their financial performance is weak & -.291 & .661 & .105 \\
\hline CSR depends on the strategies of the competitors & -.342 & 0.038 & .129 \\
\hline $\begin{array}{l}\text { CSR contributions are more if the corporate is having well organized and self } \\
\text { regulated corporate governance system }\end{array}$ & .137 &. $\mathbf{8 0 2}$ & .655 \\
\hline $\begin{array}{l}\text { CSR activities are positively related to diversity and nature of workforce } \\
\text { (employees from different nationalities studied in various business schools) }\end{array}$ & .230 & -.035 & .659 \\
\hline $\begin{array}{l}\text { CSR activities depend on the existence of stronger NGOs, private and independent } \\
\text { social organizations in the society }\end{array}$ & .742 & .317 & -.189 \\
\hline $\begin{array}{l}\text { Bank that employ performance based reward/effective staff appraisal system is } \\
\text { more } \\
\text { inclined towards CSR }\end{array}$ & .717 & .274 & -.061 \\
\hline Multinationals in top management greatly influence the CSR policy & .727 & .285 &.- .171 \\
\hline Bank spends for CSR to evade taxes & -.258 & .076 & -.396 \\
\hline Central Bank/ regulators interference increase CSR spending & -.133 & .168 &.- .477 \\
\hline $\begin{array}{l}\text { CSR policies are just only the mimics of western culture and bank in Oman try to } \\
\text { emulate multinationals in this aspect }\end{array}$ & -.212 & .666 & .092 \\
\hline \begin{tabular}{l} 
Extraction Method: Principal Component Analysis. \\
\hline a. 3 components extracted.
\end{tabular} & & \\
\hline
\end{tabular}


Table 8. Rotated Component Matrix for Factors Influencing CSR

\begin{tabular}{|l|c|c|c|}
\hline \multicolumn{1}{|c|}{ Rotated Component Matrix $^{\mathrm{a}}$} & \multicolumn{3}{|c|}{ Component } \\
\hline & 1 & 2 & 3 \\
\hline Bank is less likely to invest in CSR if their financial performance is weak & -.037 & .728 & -.039 \\
\hline CSR depends on the strategies of the competitors & -.036 & .109 & -.042 \\
\hline $\begin{array}{l}\text { CSR contributions are more if the corporate is having well organized and self } \\
\text { regulated corporate governance system }\end{array}$ & -.007 &. $\mathbf{8 8 0}$ & .661 \\
\hline $\begin{array}{l}\text { CSR activities are positively related to diversity and nature of workforce (employees } \\
\text { from different nationalities studied in various business schools) }\end{array}$ & .049 & .011 &. $\mathbf{6 9 7}$ \\
\hline $\begin{array}{l}\text { CSR activities depend on the existence of stronger NGOs, private and independent } \\
\text { social organizations in the society }\end{array}$ &. $\mathbf{8 2 8}$ & .006 & -.008 \\
\hline $\begin{array}{l}\text { Bank that employ performance based reward/effective staff appraisal system is more } \\
\text { inclined towards CSR } \\
\text { Multinationals in top management greatly influence the CSR policy }\end{array}$ & .807 & -.018 & .125 \\
\hline Bank spends for CSR to evade taxes & .800 & -.015 & .008 \\
\hline Central Bank/ regulators interference increase CSR spending & -.116 & .085 &.- .456 \\
\hline $\begin{array}{l}\text { CSR policies are just only the mimics of western culture and bank in Oman try to } \\
\text { emulate multinationals in this aspect }\end{array}$ & .049 & .112 & -.509 \\
\hline $\begin{array}{l}\text { Extraction Method: Principal Component Analysis. } \\
\text { Rotation Method: Varimax with Kaiser Normalization. }\end{array}$ & .704 & -.030 \\
\hline a. Rotation converged in 4 iterations. & & \\
\hline
\end{tabular}

\section{Conclusions}

The aim of this research is to study the factors that influence bank's CSR from stakeholders' perspective.

The following are the major inferences from the research carried out:

1. Stakeholders believe that financial performance is not a factor to determine the CSR pursuits of the banks. This is also substantiated by the fact that there was no budgetary cut from the banks on CSR during the period of economic recession (Business Today, January, 2010).

2. It is found that banks do not phase their CSR based on the strategies of its competitors. It may be due to the fact that all banks are operating in niche area and have diversified stakeholder's base. So a strategy adopted by a bank may not suit for others. Moreover targeting similar potential beneficiaries in the society or targeting specific segment is itself a bad strategy and may lead to negative publicity. These results match with the findings of Albinger \& Freeman (2000); Backhaus et al. (2002). In their work, it is mentioned that benefits of CSR include allowing a firm to differentiate itself from competitors and raising its profile amongst its customers and employees. . 
3. CSR contributions of a bank are positively related to the well organized corporate governance system. This view is in agreement with that of Beltratti (2005). In this paper, the author remarked the complementary association of corporate governance and CSR in achieving the goals of the organization and in facing the constraints faced by the corporations. Stakeholders are having difference in their agreement as local community rates this relatively lower. This may be due to the lack of awareness about the role of corporate governance and its role in CSR policy making process.

4. CSR activities are related to the diversity and nature of the workforce. It indicates the need to have employees from different background transcending the nationality barriers who could bring value to the firm through their education, experience and culture with different schools of thoughts to emerge better CSR policy. Stakeholders' views are in line with that of Kirton \& Greene (2005). In their work, it is quoted that inequalities in employment are unjust and unfair and it is the social responsibility of companies to address this by having a managing diversity policy. Backhaus et al. (2002) in their study of CSP and employer attractiveness consider the treatment of employees and workplace diversity to be particularly important signals of CSP, as these have a more significant and direct effect on the individual employee than other dimensions of CSR such as the environment, community relations or product issues. However this view is not uniform across all stakeholders and is not adequately supported by the customers and local community.

5. Stakeholders of banks in Oman are united in agreeing to the fact that presence of nongovernmental, social and independent private organizations as a factor to boost the bank's involvement for social cause. This could be visualized in two angles. One is due to the fact the banks are specialized in carrying out business related issues apart from its service to customers. So the presence of social and charity organizations in the country allows the banks to earmark the funds for CSR and nominate social organizations to take care of social responsible activities on their behalf. This will avoid the risk of banks in identifying the wrong beneficiaries for their CSR programs or difficulties faced in indentifying the appropriate recipients. Another way is that there will be always pressure from social organizations to convince the corporate for sponsoring social and charity programs. Jonker \& Nijhof (2006) studied the interaction between NGOs and companies. It is mentioned that there is close interaction between social/nonprofit organizations with the companies in the area of CSR.

6. Bank that employs performance based appraisal system is considered to be favourable for CSR as it shows the promptness of the firm to recognize and reward the performing employees. This kind of corporate system is known for its proficiency in human resource management. Simmons (2003) used stakeholder analysis to examine issues of performance, accountability and equity in organizations; and to identify implications for more socially responsible human resource practice. This approach paved the way for the reconciliation of effective governance with social responsibility and incorporation the stakeholder views in human resource management to enhance the organization's performance and commitment. This is not uniformly supported by al stakeholders as customers and investors rate it at low. 
7. Stakeholders support the view that mmultinationals in top management greatly influence the CSR policy. This may be due to the fact that multinationals bring diversity into policy formulation because of their affiliation to different business schools of thoughts.

8. Stakeholders disagree to the view that bank spends for CSR to evade taxes. This view emerges due to the sincere efforts taken by the banks for their social cause. Also tax evasion can be achieved by other means rather than spending to the community. There is considerable difference in the degree of disagreement as customer and local community rate show difference in their disagreement when compared to other stakeholders. Internal stakeholders such as employees and managers are strongly disagreeing to this opinion. This view is substantiated by the absence of any government policy in the country to offer tax incentives for corporation involved in CSR projects.

9. The view of central bank/ regulators interference makes the banks to spend more on CSR is not approved by the stakeholders though significant difference in the degree of disagreement. Central bank or regulators are more concerned towards the fair business practices, bank's compliance to the government directives, proper reporting and audit control. They may not dictate the terms regarding CSR. However there is some difference among the stakeholders especially due to customers rating.

10. Regarding the view that CSR policies are just only the mimics of western culture and banks in Oman are try to emulate multinationals. This is no significant difference among the stakeholders in disagreeing to this view. This is due to indigenous nature of the bank's CSR policy. These policies are aimed to serve the local community and cater to the demands of the people in the country.

This research has identified the three principal factors i.e. presence of nongovernmental organizations and social organizations, good corporate governance system and diversity of the workforce to predominantly influence the CSR activities of banks as shown in Fig.1.

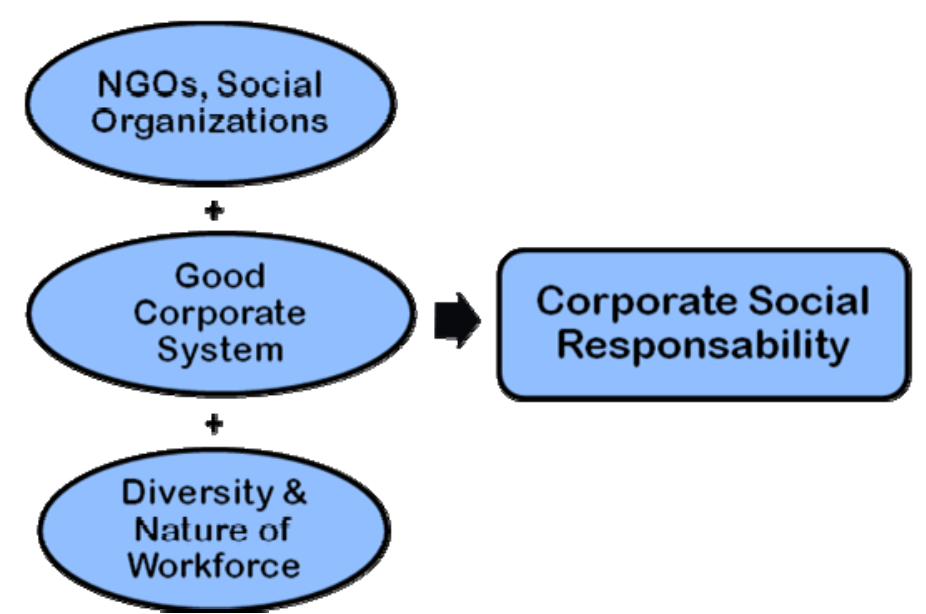

Figure 1. Principal Factors Influencing CSR from Stakeholders Perspective

\section{Acknowledgement}

Authors wish to express their gratitude to the authorities of Shinas College of Technology, Sultanate of Oman, for providing the necessary facilities and ambience to carry out this research. One of the authors (Sangeetha) would like to place on record her appreciation for 
the support extended by the authorities of Rayalaseema University, Kurnool, India for her research programme.

\section{References}

Albinger, H. \& Freeman, S. (2000). Corporate social performance and attractiveness as an employer to different job seeking populations. Journal of Business Ethics, 28, 3, 243-253.

Backhaus, K., Stone, B. \& Heiner, K. (2002). Exploring the relationship between corporate social performance and employer attractiveness. Business and Society, 41, 3, 292-318.

Beltratti, A. (2005). The complementarity between corporate governance and corporate social responsibility, The Geneva papers, 30, 373-386.

Berens, G., Riel, C. B.M \& G. H. Bruggen. (2005). Corporate Associations and Consumer Product Responses: The Moderating Role of Corporate Brand Dominance. Journal of Marketing, 69, 35-48.

Bhattacharya, C. B. \& Sen, S. (2004). Doing Better at Doing Good: When, Why, and How Consumers Respond to Corporate Social Initiatives. California Management Review, 47, 1, 9-24.

Bhattacharya, C.B., Sen, S. \& Korschun, D. (2007). Corporate Social Responsibility as an Internal Marketing Strategy. Sloan Management Review, 2007.

Business Today. (January, (2010). The Good Samaritans, CSR, 42-45, Apex Press and Publishing, Muscat, Sultanate of Oman.

Business Today. (June 2010). Market Review, Banking system in Oman: An Overview, 66-75, Apex Press and Publishing, Muscat, Sultanate of Oman.

Freeman, R. E. (1984). Strategic Management: A stakeholder approach. Pitman Publishing Boston.

Jonker,J. \& Nijhof, A. (2006). Looking Through the Eyes of Others: assessing mutual expectations and experiences in order to shape dialogue and collaboration between business and NGOs with respect to CSR. Corporate governance: an International Review, 14, 5, 456-466.

Kirton, G. \& Greene, A. (2005). The Dynamics of Managing Diversity: A Critical Approach, Elsevier Butterworth Heinemann, Oxford.

Lichtenstein, D. R., Drumwright, M.E \& Braig, B.M. (2004). The Effects of Corporate Social Responsibility on Customer Donations to Corporate-Supported Nonprofits, Journal of Marketing, 68, 16-32.

Luo, X., \& Bhattacharya, C.B. (2006). Corporate social responsibility, customer satisfaction and market value. Journal of Marketing, 70, 4, 1-18.

Maignan, I., Ferrell, O.C \& Ferrell, L. (2005). A Stakeholder Model for Implementing Social Responsibility in Marketing. European Journal of Marketing , 39, 9, 956-977.

Marin, L., Ruiz, S. \& Rubio, A (2009). The role of identity salience in the effects of corporate social responsibility on consumer behaviour. Journal of Business Ethics , 84, pp. 65-78.

Mohr, L. A., \& Webb, D.J. (2005). The Effects of Corporate Social Responsibility and Price on Consumer Responses. Journal of Consumer Affairs, 39, 1, 121-147. 
Palacios, S. (2008). Aligning Diversity, CSR and Multicultural Marketing. Harvard Business School Publishing Corporation, s1-s4.

Pirsch, J., Gupta, S \& Grau, S.L. (2007). A Framework for Understanding Corporate Social Responsibility Programs as a Continuum. Journal of Business Ethics, 70, 2, 125-140.

Sen, S \& Bhattacharya, C. B. (2001). Does doing good always lead to doing better? Consumer reactions to corporate social responsibility. Journal of Marketing Research, 38, 225-243.

Simmons, J. (2003). Balancing performance, accountability and equity in stakeholder relationships: towards more socially responsible HR practice, Corporate social responsibility and Environmental Management. 10, 3, 129-140.

Sparkes, R., \& Cowton, C.J. (2004). The maturing of socially responsible investment: a review of the developing link with corporate social responsibility. Journal of Business Ethics, 54, 45-57.

Sprinkle, G.B \& Maines, L.A. (2010). The benefits and costs of corporate social responsibility. Business Horizons, 53, 445-453. 